\title{
The Experience of Policy
}

\section{Lynda Workman}

University of Alberta

I sit quietly at my desi, aware and yet unaware of my surroundings. The character of the office dominates. Walls of neutral color, blinds and chairs of quiet pastels, and all the accoutrements of office life: steel filing cabinets overflowing with files and papers, a bookcase dominated by policy manuals, a phone ready to ring unexpectedly. And forms, rows of forms, all different for different purposes: to record information, to record statistics, to declare witnessed truths. Into this overwhelming presence there are the reflections of humanness, a picture drawn by a client and given to me in appreciation, a wall hanging of pinks and blues and greens that speaks to growth and challenge, a calligraphic hanging that defines friendship as "the inexpressible comfort of feeling safe with a person, having neither to weigh thoughts nor measure words," and books interspersed between the manuals that speak to caring, self-esteem, and what it is to be human. Two realities are present and fused in this room, the reality of human connectedness with people in the helping relationship and the reality of an organizational world of policies and procedures. Helping occurs within a policy context.

What is this policy world in which I am employed, and where I will spend a third of my life's span to help others? In Dunn's (1981) image the policy world has three parts: an environment, policies and procedures, and stakeholders. Vickers (1965) understands the policy world as a dynamic system of regulation "maintaining through time a complex pattern of relationships in accordance with standards or within limits which have somehow come to be set as governing relations" ( $p$. 27 ); such cold words to describe my living reality. The policy world is embedded in my office and it pulses with life through all that I touch, see, feel, think, and exchange in dialogue with others. The neutrality and rationality of the words of the policy world obscure but cannot eliminate the pain, the wonder, the awe, the hopefulness, the experience of it.

And so I turn to Mitroff (1983) who points to the internal space of the person in whose hands the policy comes alive. Policies offer a construct of an external environment that collects and organizes the community. But policy lives through the hands of me, the social worker. Who I am, 
the beliefs I hold, the assumptions I make color and shape the meaning of policy. What do I understand about this policy that lives through me?

\section{Policy as The Experience of Order}

I gaze at the picture on my wall, the one given to me by a client, black crayon on white paper. On the left side of the page is a tall tower made up of row upon row of uneven rocks. The base is fragile, the tower is tall, and it appears that it could fall at any moment. On the right side of the page is a similar tower, tall, uneven, and wobbly. Staggering across the page to join the two towers is a thin line, and standing at the top of one of the towers is a precarious figure of a woman about to step across. The line is fragile and the chasm is deep. There is no shining sun, there are no other people. I am frightened when I look at this drawing. I feel the fear in my body. It is the same fear I feel for the people I am supposed to serve and help. I think of Mary, a single mother of four. How can she continue to survive with such fragile supports? What is necessary? Is it money? Is it food? Is it other people? Is it me? Who is necessary? In this picture, there is only one figure. Where are the other people? Is no one interested? I want to fill the picture, I want to stabilize this world as mine is stabilized. Can I? And are there policies to help me? To help Mary? What are these policies I seem to recognize?

Policy as a word is familiar and used with all the confidence and comfort of an old shoe along a worn and comfortable path. The phrase "honesty is the best policy" cascades through my life's experience. A dictionary states that policy is " a course of action dictated by prudence or expediency." A policy analyst might say that policy is "a value-based guide to discretionary action." I ask the question of others around me, "What is policy?" There are many answers. "A preferred response to a recurring event." "Practical wisdom." "Policy is flexible, it has rules to break." "A guide." I don't know. Each answer is offered with a look that is sometimes thoughtful, sometimes quizzical, and frequently uncertain. There is a question behind the answer. Maybe it is this? Or this? Or this? It is as if we have lived with the experience of policy without full consciousness.

Policy originates from the Latin word politia meaning government and is associated with politicus meaning "polished" or "refined." These words are found in history as "suche peoples as do lyue to gethere in a cyuyle pollycye and good ordre." The words carry the ring of other generations gathering together in an ordered community life. Policy speaks to the organization of a human community that can live and work together for the betterment of all. Policy binds and unites us for our preservation as a continuing and unbroken thread. The rhythm of the seasons, the rhythm of the months, the rhythm ebbs and flows like 
a constant music singing through the ages, providing a context for all living things.

I look around my office and at the papers spilling across my desk in apparent chaos. Each paper looks the same: white paper, black print. Some are thicker than others but nothing else distinguishes them from each other. I randomly pick up a piece of paper and read. It is a memo referring to compressed work hours and requesting a review-of the policy. I pick up another. It is a request for leave without pay-there is a policy. And yet another piece of paper. It is a request for financial assistance. This one is for counseling services, this one for an exemption-from the policy. I reach for another, and another, and another. I am startled. At the root of all the pieces of paper is a policy that collects all the paper. In each request, however, a person is affected, a person with a particular, specific and individual need, more hinted at than stated, an omnipresent, not quite visible knowing that I feel but cannot read. Do I not need to know the particular? Perhaps not. The answer can be readily accessed through the policy. Is this then policy, a mechanism to create order? To establish simplicity in complexity such that not all the individual facts are necessary? Policy becomes the collected response.

I wonder if this is what Jean understands? Jean is a visiting student from China. She said to me, "In China we can't afford to think of ourselves first. There are too many people and no space. We must think first of how the action will affect the community. You are always watched by others." I was struck by the word watched, eyes always following me, knowing all about me before I might know it for myself, judging me. What would it be like to be always visible? No space for quiet and peaceful reflection? And so I asked Jean, "What is it like to be always watched?" She replied, "It is supportive. There is always someone to help and you are never isolated and alone."

Now I understand. Policy gives an orderliness to action. Milio (1986) says, "policy sets out parameters ... thus formulating modern patterns of living ... it is an inextricable and critical part of today's and tomorrow's environment" (p. 3). Policy establishes orderliness in the confusion of endless possibilities. That must be why in the reaching out of one human being to another, as in the picture on my wall, I experience my own helplessness. The inexpressible comfort of connectedness is not enough. Action is required. And so I turn to policy for the patterns of the past, the choices of the present, and predictability for the future.

\section{Policy as Guide to Action}

I pull a policy manual off the shelf. I am struck by its weight, heavy enough to have to expend energy to lift it onto my desk. I open the cover 
as I would any book. But this is not just any book. This book is large and has embossed in gold the title Policies and Procedures. My back is straight, I am leaning over a desk, I have a sense of purpose as I am about to search for an answer, or an explanation, or direction. Aren't answers wonderful? They bring clarity to confusion, they tell me what to do when I do not know, they spare me the pain of finding understanding. Perhaps that's what policies are, answers to questions that guide the collective experience. Oakeshott (1984) says:

men sail a boundless and bottomless sea, there is neither harbor for shelter nor floor for anchorage, neither starting-place nor appointed destination. The enterprise is to keep afloat on an even keel; the sea is both friend and enemy; and the seamanship consists in using the traditional manner of behavior in order to make a friend of every hostile occasion. (p. 232)

Is this, then, what policy means? It serves to help us steer a course through unknown waters? To bring us safely to shore? To protect us from the unknown shoals through a repeating course of action that brings comfort because it is known, and avoids what may be destructive? This must be it and I am comforted. I can follow the course of action. Now I know what I can say and do with a client. I can say "I am sorry, that is against our policy," or "I regret that your problem is not our mandate." Could I say this to the figure setting out to cross this bridge in my picture? Could I say this to Mary?

Lindblom (Benveniste, 1989), in writing about policy, knows about the possibilities of movement forward, but always cautiously, always incrementally, always with a sense of careful mutual adjustment. "Rules and regulations may exist, but if they do not work well, we will have to bend them. Maybe we should not change them yet because we do not know for sure whether what we are trying to do will work. Meanwhile let us bend the rules and see if we can do things differently" (p. 83). Policy, then, has an openness, a light of opportunity that I can reach for and pick up as one would a search light, and swing it in any direction to illuminate the sea. I can shine the light behind me and look into the past. Here I will find what has been done before and I can thus repeat the actions of the past, forever and forever. But I can also cast the light about me, left to right, right to left to illuminate the unknown waters and then I can plot a course in the direction I decide. And now I see that this guiding light, this policy that can create an aura of comfort and direction, contains also the seeds of liberation.

I respond to the idea of liberation. It speaks to me of freedom and room to soar above the boundedness of what is written. Policy lies flat on the page and it is dated. The manual pronounces that as of this date this must be so and carried out in such a manner by the authority of so and 
so. Do I need to understand what is written as a given? Am I not free to interpret, to see if something else will work?

\section{Policy as Interpretation}

I talked with Jane, a social worker, about this. She spoke about her first job.

I remember the confusion of that day, my excitement to be working, my concern that I be able to do the job, my desire to get it right. My first job. The entire first month was spent in orientation to the policies and the rules. We memorized them, we were tested on them, and then we practiced how to implement them. How exciting it all was. Our nervous laughter, our propped up confidence with the briefcase under our arms, and the enthusiasm that we could help. And then we were discharged into the policy world.

And for the first while, as a new staff, I remember applying the policy most industriously. Kindly, you know, and gently, but nevertheless "the policy says." I was dependent upon what was written. And then I began to learn about the policy-world and that what is said today may not truly apply in quite the same way as yesterday and so I began to use policy as it suited me and my capacities and the needs of others. And policy was only a helpful guide.

Carol worked in the passport division of the federal government.

The rules are written and they must be followed. Our rules were written in Ottawa, however, and they just don't make any sense in this location, not if we want to provide a service and avoid excessive expense at the same time, as the government expects. And so we made up informal verbal policies to avoid repercussions from written rules which don't make sense.

And so did Dan. He worked in the northern part of British Columbia with a Metis community. The housing was appalling. How do I describe appalling? Tarpapered frame shacks with a metal stack spouting heat into the cold northern sky, small windows with cracks open to the air, doors hung crazily, and inside a pot-bellied stove trying to keep the cold at bay. No running water, a light bulb, and children and parents huddled together to survive. Policy said that the money available couldn't be used for housing, it needed to be used for something else. But the policy didn't make sense in this northern and isolated community. And so Dan and the people built houses of logs cut by the people, stripped of their bark by the people, raised together, and insulated in the traditional way. These houses were warmer, larger, and built together. One day, quite unexpectedly, because visits by officials were rarely made, an official came and saw the houses, and questioned Dan, and he was fired.

How could this happen? Is not the exercise of interpretation guided by the interest in taking responsible action? And yet to exercise that 
responsibility for Dan was obscured and overset by a higher authority. Policy must not simply be a guide to action, with the possibilities of varied interpretations. There must be limits and consequences that rest in a higher authority. What is behind this notion of authority? Where does it originate?

\section{Policies Exercise Authority}

The policy book itself, its sheer size and weight and formality, creates a sense of authoritative officialdom. I turn the cover and I am confirmed in the matter of authority, for there it is written, "this policy is approved by the authority of city council."

Policy, then, is about authority. Authority has a voice that speaks in many tongues. There is authority as power, as in should/must do, as in orderliness, as in obedience to rules. And so I read on, wondering what I am supposed to do. This policy book has weight, has authority, has procedures. And each policy refers to another and yet another. Policy helps me to say "no" to a client. If I do not think that the problems can be best met by my organization or if I feel I do not have the skills, I can say, "It is against our policy," or when I have a situation I do not know how to handle I can say, "That is not our policy." Or I can refer problems to a higher authority that protects me.

I must soon go to see an old woman about an application for social assistance. She is poor and hungry and there is policy for giving out money. Under certain conditions and rules and affidavits sworn, money can be received. That is clear and the procedures spell out how to complete the forms, complete the declarations of honesty. I know what to do and I am secure. Policy is a contract, then, like an insurance policy, or a bond; I sign, you sign, and we are bound by these ties to be enforced with all the legal authority of a court of law.

I leave my office and travel to the inner city to visit the woman, She greets me at the door and welcomes me into her home. A wide and open welcoming smile that bids me enter. "Tea?" My heart responds to her warmth. She is an older Native woman, not yet senior but worn with years. And such a talented woman. Knitting sweaters from wool she cuts from the sheep, cards free of debris, spins into wool and knits on chopsticks into wonderful sweaters. This had been her livelihood but now her fingers are stiffening from arthritis and she can no longer work quickly enough to support herself. She wants to continue to use her gifts. She said, "I have pride in myself when I design and make a sweater. Without it, I am afraid I will become like others of my family, discounted and discarded. My fingers are painful but I feel good inside."

Policy says she is eligible for social assistance and that she can also earn $\$ 14.00$ per month and so the contract is signed. The woman signed with her $x$, I signed, and so a file was created. 
Over the following many months, she made painfully but satisfyingly, two wonderful sweaters; joyfully and lovingly created, they were ready to sell. The income from the sweaters, however, would make her ineligible for social assistance. She sold the sweaters. And I made out a declaration declaring that she had not exceeded the allowed income.

I returned to the office and told no one and wrote nothing in the file. And thus I hid my actions. But I felt disturbed and wanted to talk about the unfairness of policy, about a system that keeps others in despair and degrades their efforts. But I have learned that if I talk about not following policy, it is this old woman who will pay the price, not me in my comfortable office. Or maybe that's not true. Perhaps I would pay the same price as Dan.

I am not comfortable. I did not follow policy. I do not feel guided. I feel uncertain and guarded. Is this what policy is? When I agree with the values of the policy, when they match with mine and reassure me as a repeating song, then I remain content within the confines of my comfortable pew. But when the values embedded in the policy conflict with mine, then what? Policy is no longer the necessary mechanism for ordering community life. It has become a barrier to the sense of human connectedness, to what is real in the everyday experience: a family without housing, a woman without opportunity to benefit from her spirit. It has also become a barrier between me and those who retain authority in the policy world. The spirit of the policy has become clouded by the weight of authority that surrounds it.

Policy emerges as a multifaceted construct that attempts to organize, to set direction, and to provide supportive action. It seems to become a way of talking about our collective, our societal arrangements regarding what may be necessary and desirable for community life. The spirit of policy is intended for benefit. Yet the experience of it is fraught with ambiguity, confusion, and fear.

\section{Policy as a Test of Responsibility}

The policy experience is grounded in responsibility. I arrive into the policy-world as a paid employee with obligations to fulfill, obligations laid out in job descriptions that itemize my roles, functions, and responsibilities. I agree to the conditions, I sign an oath of confidentiality, and in exchange I receive monies for my daily bread. I have entered into a contract and I am commanded as Langford (Kernaghan \& Langford, 1990) says, to:

act in the public interest; be politically neutral; do not disclose confidential information; protect the privacy of citizens and employees; provide efficient, effective, and fair service to the public; avoid conflicts of interest; and be accountable. (p. 2) 
And I am commanded by my responsibilities as a professional to a Code of Ethics. This Code directs how I will stand in relation to others. The demands are clear: I will honor the rights of others to self-determination; I will advocate for the betterment of others; I will be strong when others may not be; I will be responsible. These obligations do not sit lightly on my shoulders. I cannot dance and flit about in the sunlight landing lightly here and lightly there. They are a weight, not as a yoke that drags me to the ground, not as a burden that bends my back to carry them, but rather as a constant presence that requires that I stand tall, on sturdy legs that carry me with purpose. And I am also responsible for myself, which recognizes that I too am moved by my human frailty. Four challenges merge into one being, to carry out the daily events in the policy world. And I do not mind. I accept these obligations willingly. I am a member of my community and I wish to participate. I do not even reflect on the contradictions that exist between obligations. The contradictions and confusions create a haze, perhaps a necessary haze, for in confusion and ambiguity much can be accomplished. I am energized by the exercise of responsibility. When I take responsibility I am in charge of myself; I am uplifted and joyful with purpose. I have a deep and abiding interest in treating others responsibly and in recognition that they too are responsible for themselves and for the community in which we are joined. Thus the weight of responsibility is shared. Within this notion there is simplicity, trust, and mutual respect. And I know that in this climate there are the capacities to make choices to solve problems, to take action that creates a vibrant family and community life. This is my hope and my expectation in the exercise of responsibility. Is this the daily experience? Marjorie's story is my story.

"I am so frustrated!" says Marjorie, "and that's why I've got this cold." Her voice was strong and conveyed the intensity of her feeling.

I feel like my wings are being clipped. I'm not allowed to be my own kind of duck. I'm working against the best part of myself. I feel angry when policy is used hurtfully towards my clients, an elderly couple. I don't sleep, I'm thinking of all the stupid things and dreading the damage to the family. I feel like I have to have the energy of a knight in armor just exactly as a crusader to try to defeat the policy and I can't. The supervisor handles the policy and it's become her policy. A policy that was designed to support elderly people in their home has become transformed into a battle ground. It's demoralizing. I'm so de-energized because my supervisor can't hear. My message doesn't count. It's like I feel we're talking a different language and what is the result? My clients are diminished. To apply the policy, as the supervisor says it must be, will make them sicker and more traumatized. Not able to respond to someone's pain and to have to hold to a policy that doesn't make sense is like ripping yourself apart. So I don't always obey the rules and I don't tell. 
Jane says, "I am very careful who I say things to. People might tell. People are reluctant to talk because of their own breaking of the rules." This is the incongruity of the policy world. Policy requires interpretation and yet here there is a sense of breaking a rule for which something dreadful results. A client without support, a person fired. This is not the spirit of the policy world but it has become part of the practice, a practice that is burdensome and deenergizing. I feel that if I can just find the right person, I will be able to share this weight. I wonder how I would go about doing this. A tentative question? A vague opening of the door and see what greeting I receive? How do I learn who I can trust? And when I find that someone with whom I can safely explore my burdens, I am delighted. I have someone I can call about my struggle. I can even get advice on how to handle this policy that burdens me. But even here I feel the boundary. With you and you I can talk; with you and you I cannot. And so we talk in whispers, we close the door of my office, we change the subject when someone else enters the room and I feel constrained.

Nancy is a manager, and so she sets policy:

We have a rule in this agency that when someone is suicidal we call an ambulance. We do not go to someone's house and try to handle it ourselves. This is the rule. I answered the phone one day and a person was very upset. We spoke and I asked her where she was. She hung up. She phoned again, and when I pressed for information she again hung up. So I got into my car and went to the house where I thought she might be and I did what I had to. What I did was not a thinking thing. It was a feeling thing, from the heart, from the gut. I did what I had to do.

This is also my experience. I too recognize "a feeling thing, from the heart" and so I respond as I exercise responsibility. Will my good intent be recognized, be listened to and applauded, or will policy be picked up and rattled in my face as in Margaret's story? Is there a barrier? I asked Nancy, "Did you change the policy to allow others the choice?" "No," said Nancy. "I would not trust the staff to be able to handle it."

\section{References}

Benveniste, G. (1989). Mastering the politics of planning: Crafting credible plans and policies that make a difference. San Francisco, CA: Jossey-Bass.

Dunn, W.N. (1981). Public policy analysis. Englewood Cliffs, NJ: Prentice-Hall.

Kernaghan, K., \& Langford, J. (1990). The responsible public servant. Halifax, NS: Institute for Research on Public Policy.

Milio, N. (1986). Promoting health through public policy. Ottawa: Canadian Public Health Association.

Mitroff, I.I. (1983). Stakeholders of the organizational mind. London: Jossey-Bass.

Oakeshott, M. (1984). Political education. In M. Sandel (Ed.), Liberalism and its critics.

New York: New York University Press.

Vickers, G. (1965). The art of judgment, A study of policy making. New York: Basic Books. 